\title{
EFFECTS OF USING CHEMICAL-FREE ROOT-KNOT NEMATODE (MELOIDOGYNE INCOGNITA) CONTROL METHODS ON THE OCCURRENCE OF BLOSSOM-END ROT IN PEPPER
}

\author{
Zoltán Mándoki*, Béla Pénzes
}

Corvinus University of Budapest, Faculty of Horticultural Science

Department of Entomology, H-1118 Budapest

Villányi str. 29-43, Hungary

Received: February 22, 2012

Accepted: April 3, 2012

\begin{abstract}
Pepper takes up the largest growing area among forced vegetables in Hungary. The most significant abiotic disease problem of this plant is blossom-end rot (BER), which can cause substantial yield losses. The uptake of calcium by plants from the soil may be negatively affected by many factors such as root-knot nematodes feeding on the roots. The nematodes then impede water and nutrient transport. In Hungary, Meloidogyne incognita is the most common root-knot nematode species in greenhouses. The use of resistant cultivars is undoubtedly the most successful control method of root-knot nematodes in warm climates. Growing of resistant pepper cultivars, and grafting onto resistant rootstocks offer alternative, environmentally friendly ways of control. The main objective of this study was to investigate the effect of both growing resistant pepper cultivars and using resistant rootstocks on the occurrence of fruit showing symptoms of BER.

Research was carried out in a plastic tunnel with soil which was heavily infested with $M$. incognita. Roots of the non-resistant cultivars were moderately damaged by the pest at the end of the vegetation period. After grafting these cultivars onto two different resistant rootstocks, symptoms of damage caused by $M$. incognita were not observed on the rootstocks. There was a negligible number of galls appearing on the roots of the resistant cultivar Cinema F1. Due to the resistance properties and other characteristics of the newly bred Cinema F1, fruit of this cultivar rarely show symptoms of calcium deficiency. In most cases, there was less fruit with BER symptoms in plants grafted onto rootstocks Robusto F1 or Snooker F1. The results showed a reduction in the extent of damage caused by the root-knot nematode, and there were other beneficial effects of the rootstocks on the scions. The occurrence of fruit showing symptoms of BER was reduced.
\end{abstract}

Key words: Capsicum, calcium deficiency, root-knot nematode, grafting, resistance, rootstock, scion

\section{INTRODUCTION}

Spread over about 1,520 ha, pepper is the most important forced vegetable in Hungary (Anonymus 2011). The most significant abiotic disease problem of forced pepper is blossom-end rot (BER) which is usually induced by calcium deficiency. This disease can cause substantial yield losses. White-fleshed pepper cultivars of intensive growth are the most susceptible to BER. The uptake of calcium by plants may be impeded by high ammonium and potassium contents in the soil, anaerobic conditions, and also by the death of root tips. High relative humidity, pathogenic stem diseases, and dry or saline soils may have a negative effect on calcium uptake (Terbe and Szabó 2003). The most harmful root pest of forced pepper is Meloidogyne incognita. Feeding on the root the nematode restricts the uptake of water and nutrients, which will cause wilting of the plants or sometimes the symptoms of nutrient disorders (chlorosis, reduced growth and fruit production) (Eisenback et al. 1981). According to Bakó et al. (2010) plants moderately infested with root-knot nematodes do show the symptoms of different nutrient disorders (phosphorus, iron, calcium). Alexander and Clough (1998) studied the effects on the yield after vlies were applied and dosing with calcium nitrate was done. They took into consideration the quantity of fruit with BER symptoms, and fruit with sunscald symptoms. The application of vlies significantly decreased the quantity of fruits showing symptoms of calcium deficiency or sunscald, and increased the yield both in the early and the whole vegetation period. However, compared to the untreated control, the $34 \mathrm{~kg} / \mathrm{ha}$ or the $68 \mathrm{~kg} / \mathrm{ha}$ dosage of calcium nitrate could cause a linear increase in the yield only in the case of high-quality fruits. The marketable yield in general, did not increase. Neither dosage significantly decreased the quantity of fruit with BER. Lantos (2007) showed that the application of calcium did not necessarily reduce yield losses caused by calcium deficiency. He found that some cultivars remained symptomless even 
though they contained less calcium. Lantos then tried to develop a new cultivar less susceptible to BER, by crossbreeding. Comparing the temperature in the zone of pepper roots and the air temperature, the former has a major effect on the appearance of calcium deficiency symptoms according to Lantos et al. (2009). A prolonged period of more than $20^{\circ} \mathrm{C}$ in the zone of the root system, relative humidity above $86 \%$, low root mass, and susceptibility of the cultivar to abiotic disease all play an important role in the occurrence of calcium deficiency. If the temperature was above $22^{\circ} \mathrm{C}$ in the zone of the root system, then the uptake of calcium ions was impeded in the mediums (rockwool, perlite and soil) used for growing, in the experiments of Lantos et al. (2010). In the case of cultivar Cecil, the foliar application of a calcium-containing fertilizer every fifth day eliminated the symptoms of calcium deficiency (Parađiković et al. 2004). According to Hochmuth and Hochmuth (2009), mechanical injury, diseases of the root, and also nematodes may impede water uptake by the plant which in turn, may cause calcium deficiency. Therefore, it is necessary to control root diseases and nematodes so as to prevent BER. The main objective of this greenhouse study was to investigate the effect of growing pepper cultivars resistant to the root-knot nematode $M$. incognita as well as using rootstocks resistant to M. incognita, on the occurrence of pepper fruit showing calcium deficiency symptoms.

\section{MATERIALS AND METHODS}

The number of pepper fruits showing the symptoms of BER was investigated in an unheated plastic tunnel in Soroksár, Hungary, in the vegetation periods of 2009 and 2010. The plants were grown in soil. Openings for ventilation were located in the middle and at the ends of the $50 \mathrm{~m}$ long plastic tunnel. The soil was heavily infested with root-knot nematodes. The nematode species had been morphologically identified as $M$. incognita from the roots of tomato plants which had been previously grown in the plastic tunnel. Five different indeterminate white-fleshed pepper cultivars susceptible to the root-knot nematode, were investigated in the experiment. Seedlings of nongrafted as well as grafted cultivars were grown using two resistant rootstocks. The newly bred cultivar, Cinema F1 was also tested (Table 1). When planting, specimens were needed which were at the same developmental stage. To obtain such specimens, the seeds of the rootstocks and scions to be grafted were sown about three weeks before those of the non-grafted cultivars (Table 2). The plants were placed in double rows. The spacing between rows was $100+50 \mathrm{~cm}$, and $35 \mathrm{~cm}$ within rows. There were sixteen replicates per cultivar or rootstock-scion combination. The plants were grown with two stems, and regularly pruned. One fruit was left on every main stem and lateral shoot. In the plastic tunnel, the temperature data were recorded $50 \mathrm{~cm}$ above the ground and also in the zone of the roots using a TinyTag TGP-4510 automatic air and soil thermometer. Drip tapes were used for irrigation, humidification was performed with micro nozzles, and the plants were fertigated regularly. Calcium was applied in the forms of calcium nitrate (Yara Liva Calcinit 26,5\%
$\mathrm{CaO}$ ), a complex fertilizer containing calcium (GroGreen Grinta Calcium 13:7:20 + $8 \mathrm{CaO}$ ) and dissolved calcium (Damisol Kalcium 100 g/l CaO). In 2009 and 2010, 45 g/m² and $29 \mathrm{~g} / \mathrm{m}^{2}$ calcium oxide $(\mathrm{CaO})$ were used for fertigation, respectively. At the end of the vegetation periods, the rate of infestation with nematodes was determined by evaluating the mean number of galls/g root mass (2009), and the root surface covered by galls/total root surface (\%) (2010). While fruit picking, the number of fruit which showed the symptoms of BER were collected, recorded, and separated by plant. The rate of damaged fruit (\%) could be calculated by comparing the number of fruits with BER to the total number of fruits per plant. The data obtained were analysed using the Mann-Whitney U-test.

Table 1. The tested pepper cultivars and rootstock-scion combinations

\begin{tabular}{|c|c|c|}
\hline No. & Cultivar/Scion & Rootstock \\
\hline 1 & Cinema F1 & \\
\hline 2 & Cibere F1 & \\
\hline 3 & Century RZ F1 & \\
\hline 4 & Creta F1 & \\
\hline 5 & Kurca RZ F1 & \\
\hline 6 & Verecke F1 & Snooker F1 \\
\hline 7 & Cibere F1 & Snooker F1 \\
\hline 8 & Century RZ F1 & Snooker F1 \\
\hline 9 & Creta F1 & Snooker F1 \\
\hline 10 & Kurca RZ F1 & Snooker F1 \\
\hline 11 & Verecke F1 & Robusto F1 \\
\hline 12 & Cibere F1 & Robusto F1 \\
\hline 13 & Century RZ F1 & Robusto F1 \\
\hline 14 & Creta F1 & Robusto F1 \\
\hline 15 & Kurca RZ F1 & Robusto F1 \\
\hline 16 & Verecke F1 & \\
\hline
\end{tabular}

Table 2. The time of sowing, grafting and planting pepper

\begin{tabular}{|c|c|c|c|}
\hline Year & Sowing & Grafting & Planting \\
\hline \multirow{2}{*}{2009} & 31.03 .2009 & - & \multirow{2}{*}{10.05 .2009} \\
\cline { 2 - 3 } & 09.03 .2009 & 31.03 .2009 & \\
\hline \multirow{2}{*}{2010} & 24.04 .2010 & - & \multirow{2}{*}{01.06 .2010} \\
\cline { 2 - 3 } & 30.03 .2010 & 27.04 .2010 & \\
\hline
\end{tabular}

\section{RESULTS AND DISCUSSION}

The roots of the susceptible non-grafted cultivars were moderately damaged in both years. Compared to the non-grafted cultivars, the root of the newly bred Cinema F1 cultivar was significantly less infested with $M$. incognita. Hardly any galls could be found on the root of the Cinema F1 cultivar (Figs. 1, 3). No galls were observed on the roots of the resistant rootstocks. In 2009, Cinema F1 had less fruit with BER than any of the other non-grafted cultivars, but this difference was significant only in the case of Cibere F1 and Kurca RZ F1. With the exceptions of Verecke F1 and Kurca RZ F1 grafted onto rootstock Snooker F1, there was less fruit showing BER in the case of plants grafted onto either rootstock, than in the case of non-grafted cultivars. The aforementioned combinations ended up being excluded from the study because of unexpected damage to the roots caused by moles. This 


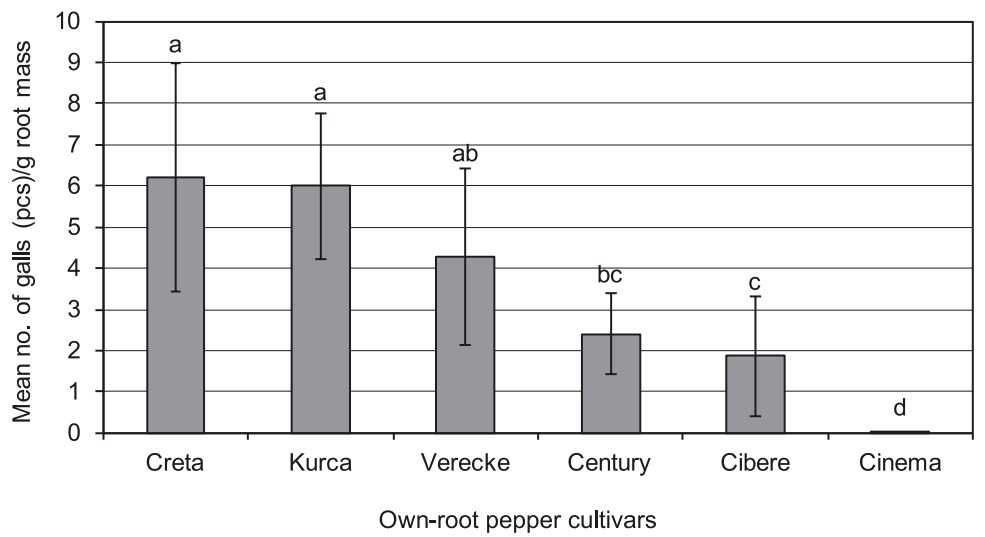

Fig. 1. Mean numbers of galls caused by the root-knot nematode M. incognita on the roots of the pepper cultivars tested (Soroksár, 2009) (means with different letters are significantly different from each other at $\mathrm{p} \leq 0.05$ )

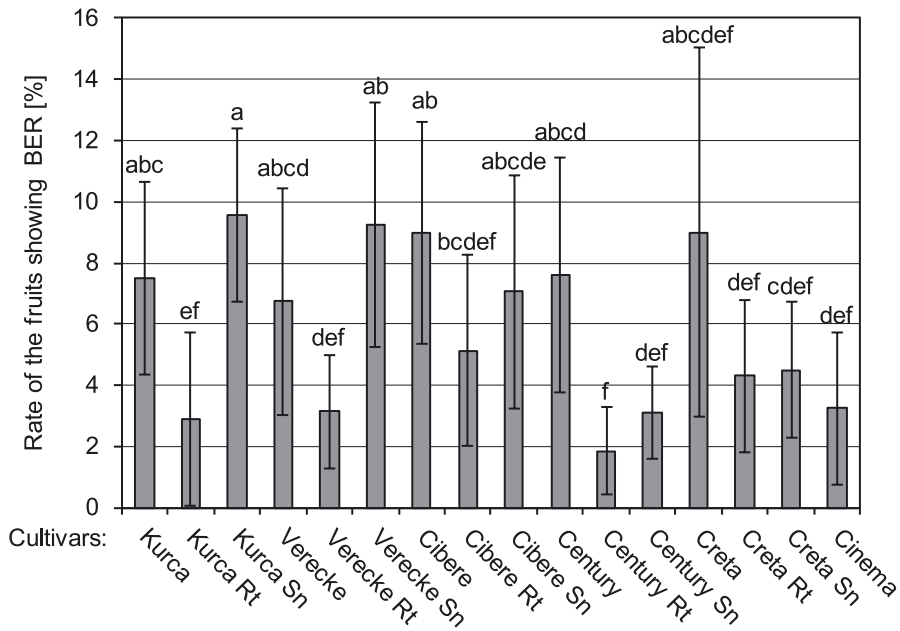

Fig. 2. Rate of the fruits showing the symptoms of blossom-end rot (BER) in the case of non-grafted and grafted peppers (Soroksár, 2009) (means with different letters are significantly different from each other at $\mathrm{p} \leq 0.05$; Sn - grafted onto Snooker F1, Rt - grafted onto Robusto F1)

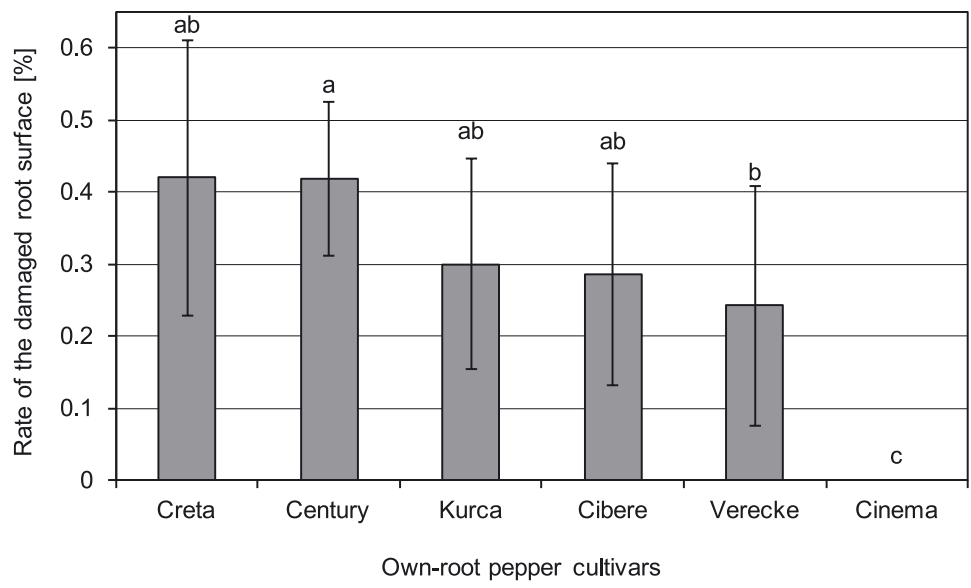

Fig. 3. Rate of the root surface covered by galls of the root-knot nematode M. incognita compared to the total root surface in the pepper cultivars tested (Soroksár, 2010) (means with different letters are significantly different from each other at $\mathrm{p} \leq 0.05$ ) 


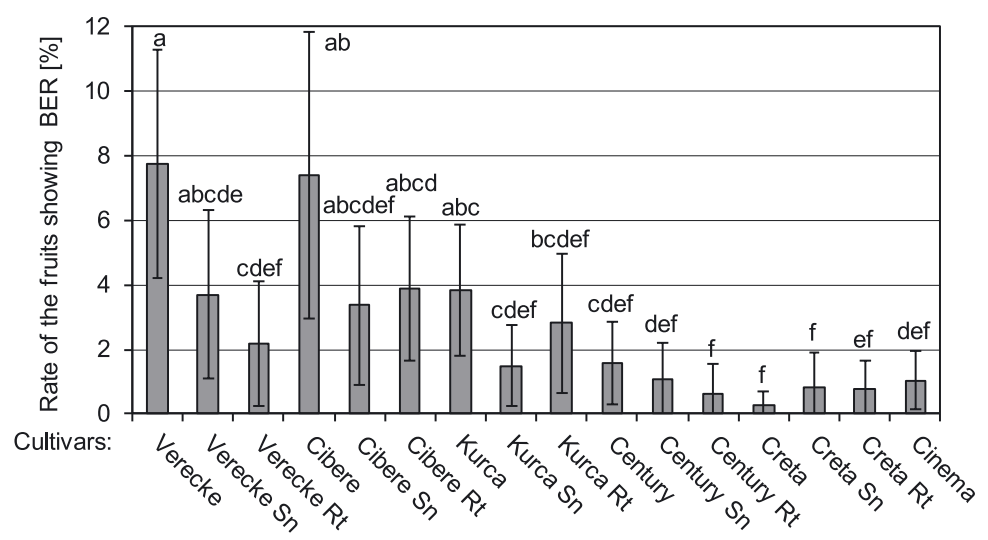

Fig. 4. Rate of the fruits showing the symptoms of blossom-end rot (BER) in the case of non-grafted and grafted peppers (Soroksár, 2010) (means with different letters are significantly different from each other at $p \leq 0.05$; Sn - grafted onto Snooker F1, Rt grafted onto Robusto F1)

damage could have contributed to the appearance of BER symptoms in the second half of the vegetation period. This latter assumption was supported by the 2010 results, which showed that fruit with BER, from both combinations, was half of that counted in the non-grafted susceptible plants (Fig. 4). In 2009, the reason for the big variance in the number of fruits with BER symptoms in the case of Creta F1 was probably the same as mentioned above. Kurca RZ F1 and Century F1 grafted onto Robusto F1 bore significantly less fruit showing BER than the nongrafted plants (Fig. 2).

In 2010, with the exception of Creta F1, all the grafted plants had less fruit with BER than the non-grafted plants. Fruit showing BER symptoms which had been picked from the grafted plants, was less than half of that from the non-grafted plants of the same cultivar in several cases. The difference was found to be significant only when Verecke F1 was compared to Verecke F1 grafted onto Robusto F1. The resistant Cinema F1 bore significantly less fruit with BER than three other non-grafted cultivars. Among the susceptible non-grafted cultivars, the least amount of fruit showing BER was found in Creta F1 (Fig. 4). The reason for this low showing was probably because of the moderate susceptibility of this cultivar compared to the susceptibility of the others. The results of this study show that occurrence of BER depends on several factors. Some cultivars, such as Creta F1, are less likely to bear fruit showing the symptoms of BER. Although approximately $35 \%$ less calcium was applied per square meter in 2010, the number of fruits with BER did not increase. This result coincides with that of Lantos's (2007), who found that the increased dosage of calcium did not decrease the occurrence of BER symptoms. The data of Hochmuth and Hochmuth (2009) may be confirmed by our results, namely that mechanical injury of roots, which was caused by moles during our experiments, may contribute to the appearance of the symptoms of BER.

Due to their resistance to the root-knot nematode and their stress tolerance (saline soils, temperature fluctuations), the rootstocks probably contribute to the better nutrition of plants. Consequently, there is less fruit showing BER on the grafted plants than on the non-grafted ones. In the case of Cinema F1, the resistance to the nematode species and other favourable properties of the cultivar may increase the amount of healthy and marketable fruit without symptoms of calcium deficiency.

Our results show that alternative and environmentally friendly, chemical-free nematode control methods (grafting onto resistant rootstocks or growing resistant cultivars) may contribute to the control of BER, the occurrence of which is partly associated with the damage caused by the pest. All the rootstock-scion combinations tested were compatible with each other, but by using other rootstocks or scions any negative effect of the former to the latter may not be excluded. By using grafted plants, not only may the yield losses caused by root-knot nematodes be reduced, but also the amount of healthy and marketable fruit may be increased.

\section{ACKNOWLEDGEMENTS}

The authors would like to thank József Fail for his contribution to this study.

\section{REFERENCES}

Alexander S.E., Clough G.H. 1998. Spunbonded rowcover and calcium fertilization improve quality and yield in bell pepper. HortScience 33 (7): 1150-1152.

Anonymus 2011. A Zöldség és Gyümölcs Ágazat Helyzete Magyarországon. [The Position of the Vegetable and Fruit Growing Sector in Hungary]. FruitVeB Magyar ZöldségGyümölcs Szakmaközi Szervezet, p. 26.

Bakó D., Bakó L., Csilléry G., Dimény J. Kassai T., Meszlényi A., Szarka J., Sztáray Z., Tégla Cs., Zentai Á. 2010. Duna Vetőmag Katalógus 2010-2011. Duna-R Kft. Budapest, p. 53.

Eisenback J.D., Hirschmann H., Sasser J.N., Triantaphyllou A.C. 1981. A Guide to the Four Most Common Species of RootKnot Nematodes (Meloidogyne species). A Cooperative Publication of the Departments of Plant Pathology and Genetics, North Carolina State University and the United States Agency for International Development: Raleigh, NC, p. 4.

Hochmuth G.J., Hochmuth R.C. 2009. Blossom-End Rot in Bell Pepper: Causes and Prevention. Soil and Water Science Department, Florida Cooperative Extension Service, Institute of Food and Agricultural Sciences, University of Florida, 5 pp. 
Lantos F. 2007. A kalcium növényélettani szerepének, jelentőségének vizsgálata a paprikatermesztésben, hiánytüneteinek visszaszorítása növénynemesítői eljárásokkal. [Study of the physiological role of calcium in paprika (Capsicum annuum) production]. Agrár- és Vidékfejlesztési Szemle 2 (2): 125-129.

Lantos F., Pék Z., Helyes L. 2009. A hajtatott paprika gyökérzóna hőmérsékletének hatása a kalciumhiányos termések megjelenésére. [Effects of root zone temperature on Ca deficiency of sweet pepper fruits, in forcing]. Kertgazdaság [Horticulture] 41 (2): 9-13.
Lantos F., Pék Z., Monostori T. Helyes L. 2010. Studies on the effects of growing substrates and physical factors in sweet pepper forcing in context with the generation of calcium deficiency symptoms. Int. J. Hortic. Sci. 16 (2): 61-65.

Parađiković N., Lončarić Z., Bertić B., Vukadinović V. 2004. Influence of Ca-foliar applications on yeald and quality of sweet pepper in glasshouse conditions. Poljoprivrede/Agriculture 10 (2): 28-31.

Terbe I., Szabó Zs. 2003. A paprika csúcsrothadásos betegségét kiváltó okok megelőzése és megszüntetése [Prevention and ceasing of the causes producing blossom end rot in paprika]. Kertgazdaság [Horticulture] 35 (1): 100-104. 